\title{
Biochemical Characterization and Antigenic Relationship of Mycoplasma mycoides subsp. mycoides. Freundt and Mycoplasma mycoides subsp. capri (Edward) Freundt
}

\author{
JAWAD M. AL-AUBAIDI, ${ }^{1}$ AHMED H. DARDIRI, and JULIUS FABRICANT ${ }^{2}$ \\ Plum Island Animal Disease Laboratory, Agricultural Research Service, Greenport, Long Island, \\ New York 11944
}

Forty-seven bovine, caprine, and ovine Mycoplasma strains were studied. Fifteen of these were $M$. mycoides subsp. mycoides Freundt; the remaining 32 were previously designated as $M$. mycoides subsp. capri (Edward) Freundt, $M$. agalactiae (Wroblewski) Freundt, or Turkish type C. Cultures of these strains were obtained from various laboratories abroad and from the Plum Island Animal Disease Laboratory repository; they included representatives of species and serotypes previously reported. The purity of all 47 cloned strains was checked by a combination of differential inhibitory methods, cloning, characterization, and serological techniques. The strains were tested for glucose fermentation, tetrazolium reduction, arginine decarboxylation, film and spots formation, hemolysis of sheep erythrocytes, inhibitory effect of $0.02 \%$ methylene blue, and methylene blue reduction. All $M$. mycoides subsp. mycoides, $M$. mycoides subsp. capri, and related strains were biochemically and serologically compared with the other strains and with representatives of a recent classification of the entire group of caprine and ovine mycoplasmas. All of the $15 \mathrm{M}$. mycoides subsp. mycoides strains gave similar biochemical reactions. Among the 32 test Mycoplasma strains, 2 of sheep origin designated Ghaleh Morghi-16 and S-5-64 were previously misidentified as $M$. agalactiae; 4 other strains were identified as Turkish $\mathrm{C}$ type. All of these Mycoplasma strains were identified as belonging to caprine and ovine group 8 . The 32 strains were divided into 2 serogroups. One group was comprised of 5 strains, including the iype strain of $M$. mycoides subsp. capri (strain PG3), and the other group contained 27 strains, including a large number previously identified as $M$. mycoides subsp. capri. All of the strains in the latter group showed an antigenic relationship to $M$. mycoides subsp. mycoides, whereas the 5 strains of the first group were serologically distinct. The 32 strains including in these 2 groups and the $15 \mathrm{M}$. mycoides subsp. mycoides strains had no antigenic relationship to Mycoplasma agalactiae, $M$. arginini, A choleplasma oculusi, or to 7 new groups of caprine and ovine Mycoplasmas. It is significant that some of the group 8 strains were isolated from goats and sheep in countries free of contagious bovine pleuropneumonia. Their antigenic identity to $M$. mycoides subsp. mycoides suggests that serious problems might arise if diagnosis of such cultures were made solely on a serological basis.

Conflicting data are recorded in the literature regarding the cross-reaction between $M y c o-$ plasma mycoides subsp. mycoides Freundt and M. mycoides subsp. capri (Edward) Freundt,

\footnotetext{
${ }^{1}$ Present address: College of Veterinary Medicine, Abu-Ghraib, Baghdad, Iraq.

${ }^{2}$ Present address: Department of Avian Diseases
}

and the classification of the latter organism has not yet been determined (13). Therefore, it is essential to discuss the history of the strains which are currently used as representatives of these organisms throughout the world.

New York State Veterinary College, Cornell University, Ithaca, N. Y. 14850. 
The Chu and Beveridge Mycoplasma strain was recovered from a goat affected with contagious caprine pleuropneumonia (CCPP) in Turkey by H. P. Chu; the strain was sent to England where it was referred to as PG3 (11). It was then designated as $M$. mycoides subsp. capri. This strain was later obtained by many laboratories and considered the reference strain of $M$. mycoides subsp. capri. At the same time, Edward (11) pointed out that Mycoplasma strains PG1 and PG3 might not belong to two different species but could belong to different subspecies of the same species; he named them Asterococcus mycoides subsp. bovis and Asteroccus mycoides subsp. capri, respectively.

The antigenic relationship of strains consanguine to $M$. mycoides subsp. mycoides and $M$. mycoides subsp. capri (PG3) were investigated by almost all available serological techniques. One of the earliest of such studies was that of Villemot and Provost (36), in which it was reported that $M$. mycoides subsp. mycoides and M. mycoides subsp. capri share only one antigen. They suggested that $M$. mycoides subsp. capri be recognized as a distinct species. Turner (35) also suggested that this subspecies be regarded as a separate species, $M$. capri. This suggestion was discussed at the first meeting of the FAO/OIE/CCTA Expert Panel on CBPP held in Melbourne, Australia, in March 1960. The panel recommended that $M$. mycoides subsp. mycoides and M. mycoides subsp. capri each be considered a distinct species of the genus Mycoplasma. Instead, PG3 has been considered to be a strain of a subspecies of $M$. mycoides and not as belonging to a distinct species. Reasons for this consideration were detailed by Edward (12).

In 1964, at the second meeting of the FAO/OIE/CCTA Expert Panel on CBPP held in Muguga, Kenya, it was recommended that strain N108, isolated by Longley in Nigeria, be regarded as the type strain of $M$. mycoides subsp. capri (Syn. Borrelomyces peripneumoniae-caprae Longley). It was reaffirmed at the third meeting of the same expert panel held in Khartoum, Sudan, in 1967, that strain N108 of $M$. mycoides subsp. capri should be regarded as the type strain of this organism. However, the indications are that this strain no longer qualifies as the type.

In the literature there is a vast number of reports on the antigenic relationship between $M$. mycoides subsp. mycoides and $M$. mycoides subsp. capri. Many researchers in this field supported this relationship whereas others disapproved of it. A number of these studies included strains other than PG3 which were recovered from goats affected with CCPP. They compared culturally, biochemically, and serologically with strains of $M$. mycoides subsp. mycoides. In addition to these studies, some researchers dealt with pathogenicity and cross protection between both $M$. mycoides subsp. mycoides and $M$. mycoides subsp. capri $(4,5$, $10,14,18,20,31,34)$.

At present, various laboratories throughout the world consider different strains as being representative of $M$. mycoides subsp. capri. The most common strains are PG3, N108, OSB42, GPS, and G11/61. In 1969, Edward and Freundt suggested that further investigations of the caprine mycoplasmas were needed to establish their relationships between each other and the organism causing CBPP (13). They added that the classification of $M$. mycoides subsp. capri must be regarded as uncertain until this has been done.

The studies reported here are part of a thorough investigation on the classification of the entire group of goat and sheep mycoplasmas. This paper is meant to clarify some of the doubts and to present new evidence regarding the biological characteristics and antigenic relationships of some caprine and ovine mycoplasmas and $M$. mycoides subsp. mycoides. The relationship of some other goat mycoplasmas which were considered antigenically similar to $M$. mycoides subsp. mycoides was also investigated.

\section{MATERIALS AND METHODS}

Mycoplasma strains. Mycoplasma strains previously identified as either $M$. mycoides subsp. mycoides, $M$. mycoides subsp. capri, or Turkish C type (9) were obtained from various laboratories around the world. Also, a large number of other mycoplasmas of goat or sheep origin, some of which were misidentified or unidentified, were also included. (Table 1 lists all strains used in this study.)

Culture media. Media for biological characterization and propagation of test mycoplasmas were prepared as described by Al-Aubaidi and Fabricant $(1,2)$.

Purification of test mycoplasmas. The purification techniques used in this study were those reported by Al-Aubaidi and Fabricant (3).

Biochemical characterization. Biochemical characterization was performed as described by Al-Aubaidi and Fabricant (2). The methods include glucose fermentation, reduction of tetrazolium chloride and methylene blue, decarboxylation of arginine hydrochloride, urease activity, formation of film and spots, inhibition of growth by $0.02 \%$ methylene blue, hemolysis of sheep red blood cells, and growth at room temperature. The ability to ferment cellobiose, galactose, glycerol, lactose, mannitol, mannose, sorbitol, saccharose, salicin, and xylose was also tested. 
TABLE 1. Origin of bovine, caprine, and ovine Mycoplasma strains studied

\begin{tabular}{|c|c|c|c|}
\hline Strain designation & Reported strain identity & $\begin{array}{l}\text { Animal } \\
\text { source }\end{array}$ & Supplied by \\
\hline PGl & M. mycoides subsp. mycoides & Bovine & E. A. Freundt, Denmark \\
\hline V5 & M. mycoides subsp. mycoides & Bovine & G. S. Cottew, Australia \\
\hline 3278 & M. mycoides subsp. mycoides & Bovine & G. S. Cottew, Australia \\
\hline Glad ysdale & M. mycoides subsp. mycoides & Bovine & G. S. Cottew, Australia \\
\hline $\mathrm{KH}_{3} \mathrm{~J}$ & M. mycoides subsp. mycoides & Bovine & G. S. Cottew, Australia \\
\hline PGl & M. mycoides subsp. mycoides & Bovine & D. G. ff. Edward, England \\
\hline T3 & M. mycoides subsp. mycoides & Bovine & D. G. ff. Edward, England \\
\hline Glady sdale & M. mycoides subsp. mycoides & Bovine & PIADL $^{a}$ \\
\hline V5 & M. mycoides subsp. mycoides & Bovine & PIADL \\
\hline $\mathrm{KH}_{3} \mathrm{~J}$ & M. mycoides subsp. mycoides & Bovine & PIADL \\
\hline Iriri & M. mycoides subsp. mycoides & Bovine & PIADL \\
\hline Afade & M. mycoides subsp. mycoides & Bovine & P. Perreau, France \\
\hline B-17 & M. mycoides subsp. mycoides & Bovine & P. Perreau, France \\
\hline S 61 & M. mycoides subsp. mycoides & Bovine & P. Perreau, France \\
\hline Fatick & M. mycoides subsp. mycoides & Bovine & P. Perreau, France \\
\hline Y-goat & M. mycoides subsp. capri & Goat & G. S. Cottew, Australia \\
\hline O-goat & M. mycoides subsp. capri & Goat & G. S. Cottew, Australia \\
\hline P-goat & M. mycoides subsp. capri & Goat & G. S. Cottew, Australia \\
\hline Mankefar (2833) & Unidentified & Sheep & E. A. Freundt, Denmark \\
\hline OSB42 & M. mycoides subsp. capri & Goat & PIADL \\
\hline Vom & M. mycoides subsp. capri & Goat & PIADL \\
\hline Acc. 143-A66 Conn. & M. mycoides subsp. capri & Goat & PIADL \\
\hline Mexico goat & M. mycoides subsp. capri & Goat & PIADL \\
\hline Acc. $208-69 \mathrm{Md}$. & M. mycoides subsp. capri & Goat & PIADL \\
\hline Acc. $222-69$ N.Y. & M. mycoides subsp. capri & Goat & PIADL \\
\hline 2605-Razi & Turkish C type & Goat & A. Foggie, Turkey \\
\hline 2105 Yamut B & Turkish C type & Goat & A. Foggie, Turkey \\
\hline 2406 Cov. 3 & Turkish C type & Goat & A. Foggie, Turkey \\
\hline 2577 Cov. 3 & Turkish C type & Goat & A. Foggie, Turkey \\
\hline 9159 Jonas goat & M. mycoides subsp. capri & Goat & A. Jonas, Conn., USA \\
\hline $1769(\mathrm{BRU})$ & M. mycoides subsp. capri & Goat & A. Foggie, Turkey \\
\hline 1177 (Vom, Longley) & M. mycoides subsp. capri & Goat & A. Foggie, Turkey \\
\hline $1488(\mathrm{EAH})$ & M. mycoides subsp. capri & Goat & A. Foggie, Turkey \\
\hline 1117 (CHU) & M. mycoides subsp. capri & Goat & A. Foggie, Turkey \\
\hline C11 (Chad) & M. mycoides subsp. capri & Goat & P. Perreau, France \\
\hline OSB42 (Sudan) & M. mycoides subsp. capri & Goat & P. Perreau, France \\
\hline Vom (Nigeria) & M. mycoides subsp. capri & Goat & P. Perreau, France \\
\hline YG (Australia) & M. mycoides subsp. capri & Goat & P. Perreau, France \\
\hline Ghaleh Morghi-16 & Unidentified & Sheep & M. Kaveh, Iran \\
\hline S-5-64 & Unidentified & Sheep & M. Kaveh, Iran \\
\hline PG3 & M. mycoides subsp. capri & Goat & PIADL \\
\hline PG3 & M. mycoides subsp. capri & Goat & E. A. Freundt, Denmark \\
\hline PG3 & M. mycoides subsp. capri & Goat & D. G. ff. Edward, England \\
\hline $\mathrm{GPA}^{b}$ & Unidentified & Goat & PIADL \\
\hline 2438 (BQT) & M. mycoides subsp. capri & Goat & A. Foggie, Turkey \\
\hline 1423 (Smith) & M. mycoides subsp. capri & Goat & A. Foggie, Turkey \\
\hline Farcha & M. mycoides subsp. capri & Goat & P. Perreau, France \\
\hline
\end{tabular}

${ }^{a}$ Plum Island Animal Disease Laboratory.

${ }^{b}$ Goat pneumonitis agent.

Production of hyperimmune sera. Hyperimmune sera to various goat and sheep mycoplasmas were produced in mature New Zealand rabbits by the method of Al-Aubaidi and Fabricant (2).

Serological procedures. Serological techniques used for the identification and comparison of all test mycoplasmas were the growth-inhibition test of Clyde (8) and the metabolic-inhibition test described by Taylor-Robinson et al. (33). The reduction of tetrazolium as an indicator system was performed according to the modified method reported by Al-Aubaidi and Fabricant (2). 


\section{RESULTS}

A total of 47 strains previously identified as M. mycoides subsp. capri, related strains of goat and sheep origin, and strains of $M$. mycoides subsp. mycoides were studied. All of the cultures were adapted for grow th in two media (RYE and basal salts [BS]). After purification of the cultures, they were subcultured several times in BS medium before their biochemical characteristics were determined. This step was taken because changing the basal broth of either the propagation medium or the characterization media could suppress the growth of the organisms. All propagated cultures grew luxuriously, producing colonies having the typical "fried-egg" appearance on agar media.

The 47 mycoplasmas used in this study are part of a larger set tentatively divided into 12 groups numbered 1 through 12 . The strains used in this investigation belonged to groups 3 and 8. Strains included in group 3 were PG3, BQT, Smith, Farcha, and GPA (goat pneumonitis agent). Twenty-five cultures representing 22 strains were placed in group 8 , and 15 strains were identified as $M$. mycoides subsp. mycoides.

Biochemical characterization. The fifteen strains of $M$. mycoides subsp. mycoides reacted similarly and gave identical biochemical reactions. Four of the strains (PG1, V5, $\mathrm{KH}_{3} \mathrm{~J}$, and Gladysdale) were duplicated, each having been received from a different laboratory. All $M$. mycoides subsp. mycoides strains tested fermented glucose, reduced tetrazolium chloride and methylene blue, and hemolyzed sheep red blood cells. They did not metabolize arginine hydrochloride or hydrolyze urea, nor did they form film and spots in egg-yolk-agar medium supplemented with $10 \%$ swine serum or grow at 25 C. However, they were all sensitive to $0.02 \%$ methylene blue. No individual strain variation or discrepancy was noted in the biochemical reactions of any of the $M$. mycoides subsp. mycoides strains studied. All 47 strains fermented glucose. There was not a sufficiently consistent fermentation of the other carbohydrates tested to make this characteristic useful for group identification at this time.

The 25 mycoplasmas listed under group 8 (caprine and ovine) fermented glucose and reduced tetrazolium chloride and methylene blue. They did not metabolize arginine hydrochloride, hydrolyze urea, or form film and spots, but they did hemolyze sheep red blood cells. There were some discrepancies in growth at $25 \mathrm{C}$ and in sensitivity to $0.02 \%$ methylene blue. Of the 25 cultures, three strains (OSB42,
Vom, and YG) were tested in duplicate; each of the duplicate cultures came from a different laboratory. All gave reactions identical to those of the original representative strains.

Mycoplasmas identified under group 3 (PG3, BQT, Smith, Farcha, and GPA) were also studied. Their cultural and biochemical characteristics resembled, to a certain extent, those of the 25 cultures listed under group 8. Discrepancies were observed in grow th at $25 \mathrm{C}$ and in sensitivity to $0.02 \%$ methylene blue. Strain PG3 was received from three different laboratories, and all three cultures gave similar biochemical reactions (Table 2).

Serological results. The metabolic inhibition test, utilizing four antisera, was used. Strains of group 3 (PG3, BQT, Smith, Farcha, and GPA) were inhibited by only PG3 antiserum at a serum titer ranging between 1:160 and 1:640. None of the $M$. mycoides subsp. mycoides of $\mathrm{Y}$ goat antisera showed metabolic inhibiting activity against group 3 strains. The 25 cultures of group 8 were inhibited by antisera to PG1 and $\mathrm{KH}_{3} \mathrm{~J}$ of $M$. mycoides subsp. mycoides and $\mathrm{Y}$ goat antiserum but not by PG3 antiserum. This inhibition was at a serum titer ranging from $1: 80$ to $1: 5,120$. All of the $15 \mathrm{M}$. mycoides subsp. mycoides cultures tested were inhibited by the specific antiserum prepared against strains PGl and $\mathrm{KH}_{3} \mathrm{~J}$ and also by $\mathrm{Y}$ goat antiserum. These were inhibited at a serum titer ranging from $1: 80$ to $1: 5,120$. The metabolic reactions reported here were very specific and reproducible even at the lower serum titers obtained in a few instances (Table 3 ).

The similarity in the metabolic reactions between the $15 \mathrm{M}$. mycoides subsp. mycoides cultures and the 25 cultures of group 8 was further investigated by testing selected strains from each group against a new antiserum prepared against strain OSB42. Again, the metabolic-inhibition test was applied, utilizing PG3, OSB42, Y goat, PG1, and $\mathrm{KH}_{3} \mathrm{~J}$ antisera. These five antisera were also applied in the grow th-inhibition test described by Clyde (8). Serological results obtained from these two methods showed that there was no difference in the metabolic inhibition reaction or growth inhibition between the $M$. mycoides subsp. mycoides cultures and any of the 25 sheep and goat cultures of group 8 . Zones of inhibited grow th ranged between 2 and $7 \mathrm{~mm}$. Results of these tests are summarized in Tables 4 and 5 .

\section{DISCUSSION}

Mycoplasmas from sheep and goats comprise several serological groups or serotypes. These 
TABLE 2. Biochemical reactions of various strains of Mycoplasma mycoides subsp. mycoides, M. mycoides subsp. capri, and related strains of cattle, goats, and sheep

\begin{tabular}{|c|c|c|c|c|c|c|c|c|}
\hline \multirow[b]{2}{*}{ Strain designation } & \multicolumn{8}{|c|}{ Determination $^{\alpha}$} \\
\hline & GF & TR & $\mathrm{AD}$ & $\mathrm{F} / \mathrm{S}$ & GR-25C & SMB-2 & GR-MG & Hemolysis \\
\hline \multicolumn{9}{|l|}{ Group 3} \\
\hline PG3 & + & + & - & - & + & + & + & + \\
\hline 2438 (BQT) & + & + & - & - & - & + & - & + \\
\hline 1423 (Smith) & + & + & - & - & - & + & - & + \\
\hline Farcha & + & + & - & - & - & + & + & + \\
\hline $\mathrm{GPA}^{b}$ & + & + & - & - & + & + & & + \\
\hline \multicolumn{9}{|l|}{ Group 8} \\
\hline$Y$-goat & + & + & - & - & + & + & + & + \\
\hline OSB42 & + & + & - & - & + & + & + & + \\
\hline Vom & + & + & - & - & + & + & + & + \\
\hline Acc. 143-A66 Conn. & + & + & - & - & + & + & + & + \\
\hline Acc. 222-69 N.Y. & + & + & - & - & + & + & + & + \\
\hline Acc. $208-69 \mathrm{Md}$. & + & + & - & - & + & + & + & + \\
\hline Mexico goat & + & + & - & - & - & + & + & + \\
\hline O-goat & + & + & - & - & - & + & + & + \\
\hline P-goat & + & + & - & - & - & + & + & + \\
\hline Mankefar (2833) & + & + & - & - & + & + & + & + \\
\hline 2605-Razi & + & + & - & - & + & + & + & + \\
\hline 2105 Yamut B & + & + & - & - & + & + & - & + \\
\hline 2406 Cov. 3 & + & + & - & - & + & + & - & + \\
\hline 2577 Cov. 3 & + & + & - & - & + & + & - & + \\
\hline 9159 Jonas goat & + & + & - & - & + & + & + & + \\
\hline $1769(\mathrm{BRU})$ & + & + & -- & - & - & + & + & + \\
\hline 1177(Vom Longley) & + & + & - & - & - & - & - & + \\
\hline $1488(\mathrm{EAH})$ & + & + & - & - & - & + & + & + \\
\hline 1117 (CHU) & + & + & - & - & - & + & - & + \\
\hline C11 (Chad) & + & + & -- & - & - & + & - & + \\
\hline Ghaleh Morghi-16 & + & + & - & - & + & + & - & + \\
\hline$S-5-64$ & + & + & - & - & + & & + & + \\
\hline \multicolumn{9}{|l|}{$\begin{array}{l}M, \text { mycoides subsp. } \\
\text { mycoides }\end{array}$} \\
\hline PG1 & + & + & - & - & - & + & - & + \\
\hline V5 & + & + & - & - & - & + & - & + \\
\hline Gladysdale & + & + & - & - & - & + & - & + \\
\hline $\mathrm{KH}_{3} \mathrm{~J}$ & + & + & - & - & - & + & - & + \\
\hline 3278 & + & + & - & - & - & + & - & + \\
\hline T3 & + & + & - & - & - & + & - & + \\
\hline Iriri & + & + & - & - & - & + & - & + \\
\hline Afade & + & + & - & - & - & + & - & + \\
\hline B-17 & + & + & - & - & - & + & - & + \\
\hline S 61 & + & + & - & - & - & + & - & + \\
\hline Fatick & + & + & - & - & - & + & - & + \\
\hline
\end{tabular}

${ }^{a}$ Abbreviations: GF, glucose fermentation; TR, tetrazolium reduction; AD, arginine decarboxylation; F/S, film and spots formation; GR-25C, growth at $25 \mathrm{C}$; SMB-2, methylene blue reduction; GR-MG, growth in $0.02 \%$ methylene blue; + , positive reaction; - , negative reaction.

${ }^{b}$ Goat pneumonitis agent.

can be identified on the basis of serological techniques and biochemical characteristics. All strains belonging to group 3 or 8 and strains of $M$. mycoides subsp. mycoides were biochemically and serologically compared to $M$. agalactiae, M. mycoides subsp. capri, and Achole- plasma oculusi and to seven new, distinct groups of sheep and goat mycoplasmas recently identified by the author. None of the group 3 or 8 strains have any antigenic relationship to the 10 new groups of caprine and ovine strains studied. The only antigenic relationship en- 
TABLE 3. Antigenic relationships among strains of Mycoplasma mycoides subsp. mycoides, $M$. mycoides subsp. capri, and related strains of cattle, goats, and sheep by the metabolic-inhibition test

\begin{tabular}{|c|c|c|c|c|}
\hline \multirow[b]{2}{*}{ Antigens } & \multicolumn{4}{|c|}{ Antisera to } \\
\hline & $\begin{array}{c}\text { M. mycoides } \\
\text { subsp. capri } \\
\text { goat group } 3 \\
\text { (PG3) }\end{array}$ & $\begin{array}{l}\text { Goat group } 8 \\
\quad \text { (Y-goat) }\end{array}$ & $\begin{array}{c}M . \text { mycoides } \\
\text { subsp. mycoides } \\
\text { (PG1) }\end{array}$ & $\begin{array}{c}\text { M. mycoides } \\
\text { subsp. mycoides } \\
\left(\mathrm{KH}_{3} \mathrm{~J}\right)\end{array}$ \\
\hline PG3 & 640 & $<10$ & $<10$ & $<10$ \\
\hline 2438 (BQT) & 640 & $<10$ & $<10$ & $<10$ \\
\hline 1423 (Smith) & 640 & $<10$ & $<10$ & $<10$ \\
\hline $\mathrm{GPA}^{a}$ & 160 & $<10$ & $<10$ & $<10$ \\
\hline Y-goat & $<10$ & 640 & 80 & 320 \\
\hline O-goat & $<10$ & 1,280 & 1,280 & 1,280 \\
\hline P-goat & $<10$ & 1,280 & 1,280 & 1,280 \\
\hline Mankefar (2833) & $<10$ & 320 & 80 & 80 \\
\hline OSB42 & $<10$ & 5,120 & 640 & 640 \\
\hline Vom & $<10$ & 640 & 80 & 640 \\
\hline 143-A66 Conn. & $<10$ & 640 & 160 & 640 \\
\hline $208-69 \mathrm{Md}$ & $<10$ & 320 & 320 & 320 \\
\hline $222-69$ N.Y. & $<10$ & 320 & 80 & 320 \\
\hline Mexico goat & $<10$ & 640 & 320 & 1,280 \\
\hline 2605-Razi & $<10$ & 640 & 320 & 320 \\
\hline 2105 Yamut B & $<10$ & 5,120 & 640 & 640 \\
\hline 2406 Cov. 3 & $<10$ & 640 & 160 & 160 \\
\hline 2577 Cov. 3 & $<10$ & 160 & 160 & 160 \\
\hline 9159 Jonas goat & $<10$ & 80 & 80 & 80 \\
\hline $1769(\mathrm{BRU})$ & $<10$ & 640 & 160 & 320 \\
\hline 1177 (Vom Longley) & $<10$ & 1,280 & 640 & 320 \\
\hline $1488(\mathrm{EAH})$ & $<10$ & 640 & 160 & 320 \\
\hline $1117(\mathrm{CHU})$ & $<10$ & 1,280 & 640 & 640 \\
\hline C 11 (Chad) & $<10$ & 1,280 & 640 & 1,280 \\
\hline Ghaleh Morghi-16 & $<10$ & 160 & 160 & 160 \\
\hline$S-5-64$ & $<10$ & 160 & 80 & 80 \\
\hline PG1 & $<10$ & 1,280 & 1,280 & 640 \\
\hline V 5 & $<10$ & 5,120 & 2,560 & 1,280 \\
\hline Glady sdale & $<10$ & 1,280 & 1,280 & 1,280 \\
\hline $\mathrm{KH}_{3} \mathrm{~J}$ & $<10$ & 320 & 1,280 & 1,280 \\
\hline 3278 & $<10$ & 5,120 & 2,560 & 2,560 \\
\hline T 3 & $<10$ & 5,120 & 5,120 & 5,120 \\
\hline Iriri & $<10$ & 1,280 & 1,280 & 640 \\
\hline Afade & $<10$ & 640 & 160 & 640 \\
\hline B-1 7 & $<10$ & 2,560 & 160 & 640 \\
\hline S-61 & $<10$ & 2,560 & 1,280 & 640 \\
\hline Fatick & $<10$ & 320 & 80 & 160 \\
\hline
\end{tabular}

${ }^{a}$ Goat pneumonitis agent.

countered in this study was between the 25 strains of group 8 and the 15 strains of $M$. mycoides subsp. mycoides. From the data presented in this study, mycoplasmas that have been identified as $M$. mycoides subsp. capri in many previous investigations can be divided into two major groups: 3 and 8 . Group 3 comprises five strains: PG3, BQT, Smith, Farcha, and GPA.

All strains in group 3 were inhibited by PG3 antiserum only. They showed no antigenic relationship to strains of group 8 or of $M$. mycoides subsp. mycoides by either of the serological methods used.

Group 8 comprises 25 cultures representing 22 strains which were also identified in many previous investigations as $M$. mycoides subsp. capri. Two strains of group 8, Ghaleh Morghi16 and S-5-64, were received from the Razi Institute, Tehran, Iran. All 25 cultures of group 
8 were inhibited by antisera to strains PG1 and $\mathrm{KH}_{3} \mathrm{~J}$ of $M$. mycoides subsp. mycoides and strain $\mathrm{Y}$ goat. At the same time, 15 other cultures representing 11 strains of $M$. mycoides subsp. mycoides gave a similar serological reaction to the strains of group 8 , which comprises 25 cultures. These 25 sheep and goat strains and the $15 \mathrm{M}$. mycoides subsp. mycoides strains were serologically indistinguishable.

All of the goat and sheep strains used in this study have been divided into two groups on the basis of metabolic-inhibition and growth-inhibition tests, although all of them had been identified in many previously reported studies as $M$. mycoides subsp. capri; those that were identified as $M$. mycoides subsp. capri were reported to have an antigenic relationship to $M$. mycoides subsp. mycoides $(4,5,10,14-17$, 20-22, 26-30, 34, 36).

The nature of the serological reaction obtained from testing the 25 strains of group 8 and the strains of $M$. mycoides subsp. mycoides did not change even upon repeated tests, and when new antiserum to strain OSB42 was used for both growth inhibition and metabolic inhibition tests.

The biochemical reactions of all goat strains tested were unique in some tests but varied in others. The discrepancies encountered in the biochemical reactions were mostly in grow th at $25 \mathrm{C}$ or growth in $0.02 \%$ methylene blue. These discrepancies were not uncommon even upon repeated tests. All $M$. mycoides subsp. mycoides strains gave identical biochemical reactions. Goat strains $B Q T$ and Smith of group 3 and strains $1117 \mathrm{CHU}$ and $\mathrm{C} 11$ of group 8 gave biochemical reactions identical to those obtained with $M$. mycoides subsp. mycoides strains. Although there are some similarities and differencies in the biochemical reactions between these two groups of $M$. mycoides subsp. mycoides, their serological reactions demonstrate that group 3 is distinct and has no antigenic relationship to $M$. mycoides subsp. mycoides or group 8 . Three cultures of group 3 were examined; these PG3 cultures were received from E. A. Freundt of Denmark, D. G. ff. Edward of England, and from the Plum Island Animal Disease Laboratory (PIADL) repository. All of these cultures reacted similarly, biochemically and serologically, upon repeated tests. Similar results were obtained with strain GPA (goat pneumonitis agent). This strain was recently recovered by the author

TABLE 4. Antigenic relationships among strains of Mycoplasma mycoides subsp. mycoides, M. mycoides subsp. capri, and related strains of cattle, goats, and sheep by the metabolic-inhibition test

\begin{tabular}{|c|c|c|c|c|c|}
\hline \multirow[b]{2}{*}{ Antigens } & \multicolumn{5}{|c|}{ Antisera } \\
\hline & $\begin{array}{c}\text { M. mycoides } \\
\text { subsp. capri } \\
\text { group 3 } \\
\text { (PG 3) }\end{array}$ & $\begin{array}{c}\text { Goat } \\
\text { group } 8 \\
\text { (OSB42) }\end{array}$ & $\begin{array}{c}\text { Goat } \\
\text { group 8 } \\
\text { (Y-goat) }\end{array}$ & $\begin{array}{l}\text { M. mycoides } \\
\text { subsp. } \\
\text { mycoides } \\
\text { (PG1) }\end{array}$ & $\begin{array}{l}\text { M. mycoides } \\
\text { subsp. } \\
\text { mycoides } \\
\left(\mathrm{KH}_{3} \mathrm{~J}\right)\end{array}$ \\
\hline PG3 & 640 & $<10$ & $<10$ & $<10$ & $<10$ \\
\hline $2438(\mathrm{BQT})$ & 320 & $<10$ & $<10$ & $<10$ & $<10$ \\
\hline 1423 (Smith) & 320 & $<10$ & $<10$ & $<10$ & $<10$ \\
\hline Farcha & 160 & $<10$ & $<10$ & $<10$ & $<10$ \\
\hline $\mathrm{GPA}^{a}$ & 160 & $<10$ & $<10$ & $<10$ & $<10$ \\
\hline OSB42 & $<10$ & 160 & 5,120 & 640 & 640 \\
\hline Y-goat & $<10$ & 320 & 640 & 80 & 320 \\
\hline Vom (PIADL) & $<10$ & 160 & 640 & 80 & 640 \\
\hline Vom (Nigeria) & $<10$ & 160 & 320 & 640 & 5,120 \\
\hline 143-A66 Conn. & $<10$ & 2,560 & 1,280 & 160 & 1,280 \\
\hline 222-69 N.Y. & $<10$ & 160 & 320 & 80 & 320 \\
\hline $208-69 \mathrm{Md}$. & $<10$ & 320 & 320 & 320 & 320 \\
\hline Mexico goat & $<10$ & 640 & 640 & 320 & 1,280 \\
\hline O-goat & $<10$ & 1,280 & 1,280 & 1,280 & 1,280 \\
\hline PG1 & $<10$ & 160 & 1,280 & 320 & 640 \\
\hline $\mathrm{KH}_{3} \mathrm{~J}$ & $<10$ & 80 & 1,280 & 1,280 & 1,280 \\
\hline Afade & $<10$ & 320 & 640 & 320 & 1,280 \\
\hline B-17 & $<10$ & 1,280 & 2,560 & 160 & 640 \\
\hline V-5 & $<10$ & 640 & 1,280 & 1,280 & 640 \\
\hline
\end{tabular}

${ }^{a}$ Goat pneumonitis agent. 
TABLE 5. Antigenic relationships among strains of Mycoplasma mycoides subsp. mycoides, $M$. mycoides subsp. capri, and related strains of cattle, goats and sheep by the growth-inhibition test

\begin{tabular}{|c|c|c|c|c|c|}
\hline \multirow[b]{2}{*}{ Antigens } & \multicolumn{5}{|c|}{ Antisera } \\
\hline & $\begin{array}{c}\text { M. mycoides } \\
\text { subsp. capri } \\
\text { group } 3 \\
\text { (PG3) }\end{array}$ & $\begin{array}{c}\text { Goat } \\
\text { group 8 } \\
\text { (OSB42) }\end{array}$ & $\begin{array}{l}\text { Goat } \\
\text { group 8 } \\
\text { (Y-goat) }\end{array}$ & $\begin{array}{l}\text { M. mycoides } \\
\text { subsbp. } \\
\text { mycoides } \\
\text { (PG1) }\end{array}$ & $\begin{array}{l}\text { M. mycoides } \\
\text { subsp. } \\
\text { mycoides } \\
\left(\mathrm{KH}_{3} \mathrm{~J}\right)\end{array}$ \\
\hline PG3 & $3^{a}$ & - & - & - & _- \\
\hline 2438 (BQT) & 3 & - & - & - & - \\
\hline 1424 (Smith) & 3 & - & - & - & - \\
\hline Farcha (Chad) & 4 & - & - & - & - \\
\hline GPA & 2 & - & - & - & - \\
\hline Vom (Chad) & - & 4 & 6 & 5 & 6 \\
\hline Vom (PIADL) & - & 2 & 2 & 2 & 2 \\
\hline Mexico goat & - & 3 & 3 & 2 & 2 \\
\hline OSB42 & - & 3 & 3 & 3 & 4 \\
\hline Y-goat & - & 3 & 4 & 3 & 3 \\
\hline O-goat & - & 3 & 3 & 2 & 2 \\
\hline 143-A66 Conn. & - & 2 & 2 & 2 & 2 \\
\hline $208-69 \mathrm{Md}$. & - & 2 & 2 & 2 & 2 \\
\hline 222-69 N.Y. & - & 2 & 3 & 2 & 2 \\
\hline PG1 & - & 4 & 5 & 4 & 4 \\
\hline $\mathrm{KH}_{3} \mathrm{~J}$ & - & 3 & 4 & 5 & 4 \\
\hline V 5 & - & 3 & 4 & 5 & 4 \\
\hline Iriri & - & 6 & 6 & 7 & 7 \\
\hline Afade & - & 3 & 4 & 3 & 4 \\
\hline Fatick & - & 3 & 4 & 3 & 4 \\
\hline
\end{tabular}

${ }^{a}$ Measurements expressed in millimeters.

from a piece of lung tissue kept frozen at PIADL since 1951. Originally the lung tissue was sampled from a goat affected with CCPP in Turkey. This strain was inoculated intratracheally into a normal goat. The goat died 4 days postinoculation. Upon necropsy, typical CCPP was noted.

Strain PG3 was unable to provoke pathological reactions in goats and sheep and failed to show any cross-reaction with $M$. mycoides subsp. mycoides (14). In a separate study, Cottew et al. (10) showed that PG3 has no serological relationship with $M$. mycoides subsp. mycoides. Turkish type C strains (Razi, Yamut B, Cov. 3 [2406] and Cov. 3 [2577]) (10) were classified in our group 8 . These strains were found to be indistinguishable from those of M. mycoides subsp. mycoides. The Razi strain is regarded as the etiological agent of CCPP in Iran. It has also been reported that strains BQT, Smith, and N108 are serologically related and that Cov. 3, Yamut B, Razi, OSB42, and Vom are related to $M$. mycoides subsp. mycoides (10). The work reported in this investigation agrees with that reported by
Hudson et al. (17) and Cottew et al. (10). Strain N108 was not available to us. However, results reported by Cottew et al. (10) and those reported in this investigation conflict with those reported by El-Nasri (14), who found that OSB42 and M. mycoides subsp. mycoides do not cross-react in the agglutination test. In our hands, strains OSB42 and $M$. mycoides subsp. mycoides (PG1 and $\mathrm{KH}_{3} \mathrm{~J}$ ) were found to be serologically indistinguishable by the metabolic-inhibition and growth-inhibition tests.

Some group 8 strains were isolated from goats and sheep in countries free of CBPP. Brack strain (Mankefar 2833) was first recovered from the tissues of a maned sheep in a zoo in Frankfurt, Germany (7). There were no clinical signs in the infected sheep, but pathological studies revealed myocarditis and polyarthritis. The present investigation demonstrates, for the first time, that the Brack strain (obtained from E. A. Freundt of Denmark) is serologically indistinguishable from $M$. mycoides subsp. mycoides, although Germany is considered free of CBPP. 
Another example is strain $O$ goat recovered from a goat with polyarthritis in New Guinea. It was reported that it is serologically indistinguishable from strains Gladysdale and V-5 of $M$. mycoides subsp. mycoides and that it is pathogenic for cattle (17). New Guinea is also considered free of CBPP. The present studies report on this antigenic relationship also, and strain $\mathrm{O}$ goat was placed in our group 8 .

A further example is the recovery of three mycoplasmas from goats in Connecticut (Accession 143-66), Maryland (Accession 208-69), and New York State (Accession 222-69). The present investigation demonstrates that all these strains are serologically indistinguishable from strains belonging to our group 8 and $M$. mycoides subsp. mycoides. The three isolates were serologically distinct from PG3. All of these strains were reported to have been lethal to goats, sheep, and calves upon experimental administration (6). This report (6) is the second published investigation of goat strains serologically indistinguishable from strains of $M$. mycoides subsp. mycoides capable of killing calves. The first experimental case was reported by Hudson et al. (17).

It has been demonstrated (22) that infected lung material from cases of CBPP and CCPP tested in cattle, sheep, and goats indicated that the same dosage of inoculum which produced disease in the specific host caused neither clinical signs nor pathological lesions in the other species. The studies reported by El-Nasri (15) confirm those of Lindley and Abdulla (22) in which they showed that strains PG3 and OSB42 had no effect on inoculated goats and bulls, and $M$. mycoides subsp. mycoides and $M$. mycoides subsp. capri did not cross-protect.

At present, many laboratories throughout the world are using their own reference strains of $M$. mycoides subsp. capri. The most commonly used strains are PG3, N108, OSB42, Vom, GPS, $\mathrm{G} 11 / 61$, and $\mathrm{Y}$ goat. It was recommended at the second meeting of the FAO/OIE/CCTA Expert Panel on CBPP in 1964 that strain N108 be regarded as the type strain for $M$. mycoides subsp. capri. This strain was considered to be Longley's original strain, but it has been exchanged between laboratories for so long that its authenticity can no longer be depended upon. Its validity is further questioned because of the several conflicting reports on its pathogenicity and antigenic relationship to $M$. mycoides subsp. mycoides. These reports included strains N108, OSB42, GPS, and G11/61 $(10,14,15)$.

This study demonstrated that all strains of group 3 formed one distinct serological group.
They have no antigenic relationship to group 8 or to M. mycoides subsp. mycoides by the metabolic-inhibition and growth-inhibition tests. Therefore, strain PG3 appears to be an acceptable representative of the subspecies, and it should be designated as the neotype strain of M. mycoides subsp. capri.

As for the 25 strains of group 8 which were serologically indistinguishable from each other and from strains of $M$. mycoides subsp. mycoides, all should be considered as $M$. mycoides subsp. mycoides of caprine and ovine origin, with strain $Y$ goat being the representative of group 8 . This strain was recovered from the peritonial fluid of a goat that died of diffuse fibrinous peritonitis in Australia (19). At present, this strain is the only pathogenic mycoplasma strain of goat origin which has not been involved in the controversial reports of the nature of $M$. mycoides subsp. capri. This strain is the most thoroughly investigated strain among goat mycoplasmas, having been reported in almost every study cited here. This strain is very virulent and can cause acute, fatal peritonitis in sheep and goats; it is very well preserved in many laboratories. For these reasons, strain $\mathrm{Y}$ goat can well represent group 8 ( $M$. mycoides subsp. mycoides of caprine and ovine origin) because, like other members of this group, it is serologically indistinguishable from strains of $M$. mycoides subsp. mycoides.

Although group 8 is serologically indistinguishable from $M$. mycoides subsp. mycoides, most of the pathogenicity studies done with strains of this group have revealed that they are not pathogenic for cattle.

\section{ACKNOWLEDGMENTS}

The cooperation of G. S. Cottew, D. G. ff. Edward, E. A. Freundt, P. Perreau, A. Foggie, and M. Kaveh for the supply of mycoplasmas is greatly acknowledged. Vincent Stopinski's excellent technical assistance is also acknowledged.

\section{LITERATURE CITED}

1. Al-Aubaidi, J. M., and J. Fabricant. 1968. Technics for the isolation of mycoplasma from cattle. Cornell Vet. 58:555.

2. Al-Aubaidi, J. M., and J. Fabricant. 1971. Characterization and classification of bovine mycoplasma. Cornell Vet. 61:490.

3. Al-Aubaidi, J. M., and J. Fabricant. 1971. Methods for the purification of mixed cultures of mycoplasma. Cornell Vet. 61:559.

4. Argaman, M., and S. Razin. 1969. Antigenic properties of mycoplasma organisms and membranes. J. Gen. Microbiol. 55:45. 
5. Arisoy, F., J. R. Etheridge, A. Foggi, and O. Erdag. 1970. Contagious caprine pleuropneumonia. A study of caprine mycoplasma strains using a cross protection test in mice. Pendik Vet. Kontr. Arastirma Enst. Derg. 2: no. 2.

6. Barber, T. L., and R. J. Yedloutschnig. 1970. Mycoplasma infections of goats. Cornell Vet. 28:297.

7. Brack, M. Von. 1966. Mycoplasma bei jungen Mahnenspringerm (Ammotragus lervia). Berlin. Muenchen. Tierärztl. Wochenschr. 79:169.

8. Clyde, W. A. 1964. Mycoplasma species identification based upon growth inhibition by specific antisera. J. Immunol. 92:958.

9. Cottew, G. S., W. A. Watson, F. Arisoy, O. Erdag, and L. S. Buckley. 1968. Differentiation of M. agalactiae from other mycoplasma of sheep and goats. J. Comp. Pathol. 78:275.

10. Cottew., W. A. Watson, O. Erdag, and F. Arisoy. 1969. Mycoplasma of caprine pleuropneumonia in Turkey and their relationship to other mycoplasma of goats and M. mycoides var. mycoides. J. Comp. Pathol. 79:541.

11. Edward, D. G. ff. 1953. Organisms of the pleuropneumonia group causing disease in goats. Vet. Rec. 65:873.

12. Edward, D. G. ff. 1960 . Letters to the editor. Int. Bull. Bacteriol. Nomencl. Taxon. 10:256.

13. Edward, D. G. ff. and E. A. Freundt. 1969. Classification of the mycoplasmatales, p. 147-200. In L. Hayflick, the mycoplasmatales and the L-phase of bacteria. Appleton-Century-Crofts, New York.

14. El-Nasri, M. 1967. Mycoplasma from contagious caprine pleuropneumonia. Ann. N.Y. Acad. Sci. 143:298.

15. El-Nasri, M. 1971. Studies on M. mycoides var. mycoides and $M$. mycoides var. capri. I. Crosspathogenicity and cross-protection test. FAO/OIE/OAU Fourth Expert Panel on Contagious Bovine Pleuropneumonia. Paris, France.

16. Griffin, R. M. 1969 . Antigenic relationships among strains of Mycoplasma mycoides var. mycoides, $M$. capri and $M$. laidlawii revealed by complement fixation test. J. Gen. Microbiol. 57:131.

17. Hudson, J. R., G. H. Cottew, and H. E. Adler. 1967. Diseases of goats caused by mycoplasma. A review of the subject with some new findings. Ann. N.Y. Acad. Sci. 143:287.

18. Jonas, A. and T. L. Barber. 1969. Mycoplasma mycoides var. capri isolated from a goat in Connecticut. J. Infec. Dis. 119:126.

19. Laws, L. 1956. A pleuropneumonia-like organism causing peritonitis in goats. Aust. Vet. J. 32:326-329.

20. Lemcke, R. M. 1964. The serological differentiation of mycoplasma strains (pleuropneumonia-like organisms) from various sources. J. Hyg. 62:199.
21. Lemcke, R. M., J. E. Shaw, and B. P. Marmion. 1965. Related antigens in Mycoplasma pneumoniae and Mycoplasma mycoides var. mycoides. Aust. J. Exp. Biol. Med. Sci. 43:761.

22. Lindley, E. P., and A. E. D. Abdulla. 1969. Some notes on the host specificity of the etiological agents of contagious caprine pleuropneumonia and contagious bovine pleuropneumonia. Bull. Epizoot. Dis. Afr. 17:153.

23. Longley, E. O. 1940. Contagious pleuropneumonia of goats. Indian J. Vet. Sci. 10:127.

24. Longley, E. O. 1951. Contagious caprine pleuropneumonia. A study of the disease in Nigeria. Colon. Res. Publ. No. 7.

25. Neimark, H. E. 1970. Division of mycoplasma into subgroups. J. Gen. Microbiol. 63:249.

26. Perreau, P., P. Gayt, and J. Monnier. 1969. The fluorescent antibody method for identifying mycoplasmas. Application for the diagnosis of contagious bovine pleuropneumonia. Rev. Elevage Med. Vet. Pays Trop. 22:481.

27. Provost, A., J.M. Villemot, P. Perreau, R. Queval, and C. Borredon. 1967. Some concepts on the antigenic relationships of different mycoplasma both within and outside the group. Ann. N.Y. Acad. Sci. 143:38.

28. Razin, S. 1968. Mycoplasma taxonomy studied by electrophoresis of cell proteins. J. Bacteriol. 96:687-694.

29. Rodwell, A. W, 1967. The nutrition and metabolism of mycoplasma: progress and problem. Ann. N.Y. Acad. Sci. 143:88.

30. Rodwell, A. W. 1969. The supply of cholesterol and fatty acids for the growth of mycoplasma. J. Gen. Microbiol. 58:29.

31. Shirlaw, J. F. 1949. Studies on contagious pleuropneumonia of the goat of India. Indian J. Vet. Sci. 19:181.

32. Smith, G.R. 1971. The use of mice in research on contagious bovine pleuropneumonia. Presented at Fourth Meeting of the FAO/OIE/OAU Expert Panel on Contagious Bovine Pleuropneumonia.

33. Taylor-Robinson, D., R. H. Purcell, D. C. Wong, and R.M. Chanock. 1966. A color test for the measurement of antibody to certain mycoplasma species based upon the inhibition of acid production. J. Hyg. 64:91.

34. Tully, J. G. and S. Razin. 1968. Physiological and serological comparisons among strains of $M y \mathrm{co}$ plasma granulorum and Mycoplasma laidlawii. J. Bacteriol. 95:1504.

35. Turner, A. W. 1960. Letters to the editors. Int. Bull. Bacteriol. Nomencl. Taxon. 10:256.

36. Villemot, J. M., and A. Provost. 1959. Recherches immunologiques sur la peripneumonia. V. Relations antigeniques entre Mycoplasma mycoides var. mycoides, $M$. mycoides var. capri et al autres micro organisms du genre mycoplasma. Rev. Elevage Med. Vet. Pays Trop. 12: 251. 